\title{
The age-performance relationship in the general population and strategies to delay age related decline in performance
}

\author{
Geoffroy Berthelot ${ }^{1,2,3^{*}+}$ (D), Stacey Johnson ${ }^{4 \dagger}$, Philippe Noirez ${ }^{1,2+}$, Juliana Antero ${ }^{1,2}$, \\ Adrien Marck ${ }^{1,2,3}$, François-Denis Desgorces ${ }^{1,2}$, Fabien Pifferi ${ }^{5}$, Patrick A. Carter ${ }^{6}$, \\ Michael Spedding ${ }^{7}$, Archana Singh Manoux ${ }^{8,9}$ and Jean-François Toussaint ${ }^{1,2,10}$
}

\begin{abstract}
The age-performance relationship describes changes in the organism's structural and functional capabilities over the course of the lifespan. The typical, empirical pattern is an asymmetrical inverted- $U$ shape association with peak capacity occurring early in life. This process is well described in the literature, with an increasing interest in features that characterize this pattern, such as the rate of growth, age of peak performance, and rate of decline with aging. This is usually examined in cohorts of individuals followed over time with repeat assessments of physical or cognitive abilities. This framework ought to be integrated into public health programs, embedding the beneficial (such as physical or cognitive training) or adverse effects (such as chronic diseases or injuries) that respectively sustain or limit capabilities. The maintenance of physical or cognitive performances at older ages would result in both optimal health and promote resistance to disabling conditions and chronic diseases, such as obesity and type 2 diabetes. The causes of accelerated degeneration of health optima are mainly: sedentary and unhealthy lifestyles -including poor nutrition-, exposure to environmental pollutants, and heterogeneity in aging. Better knowledge of optima, compatible with or required for good health, should also allow for establishing ideal conditions for longevity.
\end{abstract}

Keywords: Aging, Performance, Age-performance, Public health

\section{Introduction}

There has always been a large interest in the physiological limits of mankind. Measuring human capabilities in physical or cognitive performances or assessing maximal lifespan illustrates such a quest [1]. Such an approach focuses on sports performance, including the precise quantification of speed, strength, or endurance among others for the investigation of maximal physical capabilities. Comprehensive data-sets have allowed description and forecast improvements in physical performance during the past several decades [2]. This research suggested a finite evolution with an S-shaped growth over

*Correspondence: geoffroy.berthelot@insep.fr

${ }^{\dagger}$ Geoffroy Berthelot, Stacey Johnson and Philippe Noirez contributed equally to this work.

${ }^{1}$ IRMES, INSEP, 11 avenue du Tremblay, 75012 Paris, France

EA 7329, Université de Paris, 12 rue de l'Ecole de Médecine, 75006 Paris, France Full list of author information is available at the end of the article time, revealing considerable improvements in sport performances, that reached a plateau in the 1990's. This growth has been punctuated by improvements related to major technological advances in materials, aerodynamics, training techniques, pharmacology - including doping and biomechanics. However, despite recent innovations, data now suggests that top performances exhibit a major slowdown in progression, and even a plateau in some events [2]. As the relative gap between performances has narrowed, greater attention has been paid to environmental factors such as nutrition, psychosocial context, injury prevention/rehabilitation, and performance tracking. In order to guide talent detection and development, further insight may also come from a better understanding of the age-related changes in performance. A lifespan approach may also help in assessing the effects of injuries and recovery [3].

Use of the sports performance paradigm provides an important approach to study the age-related development 
in physical or cognitive capabilities and to understand the effects of aging over the lifecourse. The advances in technology allow the collection and exploitation of large data-sets. Knowledge gained from the study of the ageperformance relationship can now be related to health with an integrated view [4]. In this review, we detail the past and recent findings in this field from a public health perspective, relating performance patterns to the current strategies for increasing lifespan through nutrition, therapeutic interventions and physical activity.

\section{The age-performance relationship}

Aging impairs most physical [5], skill-based [6, 7], and physiological capacities [8-14]. The decline has been widely studied in sport science with a focus on measuring performance drops in master athletes [15], a feature that was heterogeneous across activities, with strength events generally associated with an earlier decline as compared to endurance ones [15]. This can be explained by the multiple biological alterations occurring with aging, such as changes in the structure and function of most organs, including skeletal muscles, heart, vessels, or the brain [16]. Research also emphasized consideration of the whole-life development and decline in human functional capacity, a useful tool in assessing the complete physical and cognitive pattern with aging [14,17-19]. The focus is on describing the positive convex hull of peak performance as a function of aging. The convex hull was found to be a continuous, asymmetrical inverted-U pattern (or $\curvearrowright$ ), where the age of peak performance occurs in the earlier part of life. The first phase of the $\frown$ is related to all intrinsic and extrinsic conditions favoring or handicapping development of functional capacity. For instance, nutritional status of the mother is associated with the weight and health status of her infants [20-23], and ultimately with their longevity $[24,25]$. This relation can be understood through the lens of a non-optimum development phase resulting in a diminished peak of performance. A low peak performance probably results in a shorter lifespan (here performance is understood as an indicator of the psychosocial and physical status). The second phase of the $\frown$ refers to age-related decline. All conditions that contribute to restricting peak performance or accelerating decline are likely to be associated with an increased pace of aging and ultimately with a shorter life expectancy. Hence, conditions that impair performance may change life history trajectories and result in increased premature mortality. For instance, the diminished respiratory function observed in rescue workers from the September 11, 2001 disaster in New York may ultimately reduce their life expectancy [26]. Air pollution in major cities is a difficulty for athletes [27], for instance the particle pollution in Addis Ababa has been a factor in the relative decline of Ethiopian athletes compared to those in Kenyan. Other studies showed the structural changes that occur in human skeletal muscles with age and found them to get weaker and smaller with advanced age (sarcopenia) [28]. Constantin et al. examined muscle biopsies from patients after $4 \mathrm{~h}$ of surgery where a similar profile was observed to that of immobilization of muscle. Levels of IL6 and TNF $\alpha$ were increased markedly which is associated with considerable inflammation-driven muscle breakdown. This is a cause of frailty in post intensive care and ageing with muscle degradation. [29]. Other biological processes associated with the performance drop have been suggested; potential candidates being persistent metabolic waste products, interactions between damaged cell components (e.g., misfolded proteins), reactive oxygen species, telomere attrition, etc. [14, 18]. These parameters have the commonality of following the rule of increased entropy [30].

\section{Estimating the age of peak performance}

The $\frown$ has generated noticeable interest in sport science as well as in public health for its consistency across performance domains. The attributes of this pattern hold valuable information such as rate of growth, age when peak performance occurs, and rate of decline. Age at peak performance allows for the optimization of the species capabilities by detecting the age of outstanding achievement, i.e. when athletes are expected to reach their peak physical condition. This was investigated in many other areas, including creative output, writing, lyric poetry, pure mathematics, theoretical physics, philosophy, medicine, general scholarship, military and diplomatic success, among others [31]. Multiple methods have been developed to estimate the age of peak performance, including typical polynomial curve fitting, mixed models, rolling means and other regression analyses [32]. Quadratic and other second-order polynomial fittings, such as in [33] and in [31], provide a poor estimate of the age of peak performance as the $\cap$ is consistently reported to be asymmetrical, with an early (i.e. before mid-life) age of peak performance [14, 17, 18, 31, 34, 35]. One of the earlier empirical approaches describing the $\cap$ was introduced by Moore in 1975 using the equation $P(t)=a\left(1-e^{-b t}\right)+c\left(1-e^{d t}\right), P(t) \geq 0$ where $a, b, c$, $d$ are four positive constants and $P(t)$ is the performance value at age $t$ [34]. He investigated the $\frown$ in 15 running and 2 throwing events in track and field and showed that this equation provided an excellent fit for the data. It has also been applied to other sports (tennis, swimming) and cognitively demanding activities (chess contests) with great accuracy $[14,17,35]$. For all these regressions, the values of $a / b$ and $c / d$ are always greater than 1 , which suggests that using a quadratic equation to describe the pattern is not efficient. Moore's approach has been criticized for having no biological or physiological meaning 
in its design, similar to most previous equations, which were constructed only from an empirical perspective [18]. We recently introduced a biological model relating cell proliferation (leading to growth) and loss in cell functionality (leading to performance decline) [18]. We showed this model could be adjusted to a set of various human and non-human physical or cognitive performances while allowing for comparisons of the resulting patterns using the normalized growth and degeneration rates. However, much experimental and methodological work is required to bridge the gap between the whole-body performance and cell biology within an aging framework.

\section{At the individual scale}

Most of the previous studies investigated the $\frown$ at the species rather than individual scale, meaning that the $\sim$ was averaged over a cohort of selected individuals. A few studies provided examples of the age-performance relationship at the individual scale -or 'trajectory'- which also exhibited a $\cap$ in track and field, swimming, chess, cycling [17, 36], and tennis [35]. An almost complete trajectory was also described in Dill's study, which investigated the trajectory of marathoner Clarence DeMar from the age of 22 to 66 years old [37]. This strengthened the main assumption that the $\frown$ is congruent, i.e. the individual and the average (species) trajectories are a $\frown$ and share similar properties, such as asymmetry and non-linear growth and decline. However, heterogeneity is null at the species scale, as the $\frown$ is defined by a convex envelope, thus representing the upper boundary of all individual's trajectories. On the other hand, a strong heterogeneity characterizes individual athlete's trajectories. Premature (with faster maturation) or delayed (with slower maturation) individuals have an age of peak performance at an earlier (resp. later) stage of life compared to the average (Fig. 1a \& b). This can be the result of multiple endogenous and exogenous factors including, but not limited to, genetic heterogeneity and varying social or environmental conditions.

\section{In other species}

From a biological point of view, such alterations with aging are also empirically measured in other species, including the nematode (Caenorhabditis elegans), mouse lemurs (Microcebus murinus), mice (Mus domesticus), greyhounds and thoroughbreds [14, 18, 38, 39]. For all studied species, the convex hull is a $\frown$, with the age of peak performance occurring earlier in life, ranging from $4.5 \%$ (mice) to $27 \%$ (grip strength in mouse lemurs) of the estimated lifespan [18]. Yet, other studies pointed out similar observations in drosophila [40,41], codling moths [42], rodents and monkeys [43], and zebrafish [44]. This research furthers knowledge on physical and mental development from the time of the first cellular division. Functional assessments provide unique phenotypic biomarkers, as well as convenient tools to measure responses to later life interventions [45]. It may also drive the design of cohorts and protocols in order to better assess the early stages of chronic pathologies, such as Alzheimer's disease, that gradually worsen with age, accelerates neuronal aging and advances the entrance into the stage of brain insufficiency (in the sense of an organ failure such as in renal or heart failure).

\section{Public health perspective}

The age-performance relationship has also been studied in the general population [46-48]. Nassif et al. investigated the age-performance relationship in French volunteers (for a total of $n=31,349$ individuals) aged between 4 and 80 years old who participated in events dedicated to measuring physical fitness [46]. They observed a $\cap$ suggesting the species pattern is consistent across elite athletes and the general population. Bongard et al. showed that the relationship between 1-hour swimming distance and age for 4271 individuals (2173 men and 2098 women), aged 19-91 years, had a non-linear (quadratic) decline [48]. This could be explained by the fact that the underlying biological mechanisms leading to decline in performance affects all individuals in a similar fashion. The picture is not as clear when analyzing the individual trajectory from a public health perspective. In fact, individual history -health \& chronic diseasesor personal lifestyle -periodic training conditions, smoking, alcohol, etc.- drive the trajectory, meaning that it may not exhibit a $\frown$ or that the age of peak performance and rate of decline may follow a heterogeneous distribution with multiple ages of peak performance, some of them occurring later in life [49] (see Fig. 2a for an example). For instance, quitting smoking with the objective of running a marathon will strongly alter an individual's trajectory. Thus, measuring performance at different ages would allow monitoring of physical ability as a proxy of physical fitness [45].

\section{Strategies to delay performance decline Physical and mental activity}

There are several strategies to modify age-related health trajectory: physical activity is thought to have beneficial effects on both physical health and mental well-being [50, 51]. As defined by the World Health Organization, physical activity is 'any bodily movement produced by skeletal muscles that requires energy expenditure' whereas exercise is 'planned, structured, repetitive and purposeful'. For purposes of this review, only physical activity measured by activity monitors was considered. It has the potential to increase lifespan while reducing the global burden of disease [52, 53]. It has an effect over the regulation of aging within and across several physiological systems [54]. For 


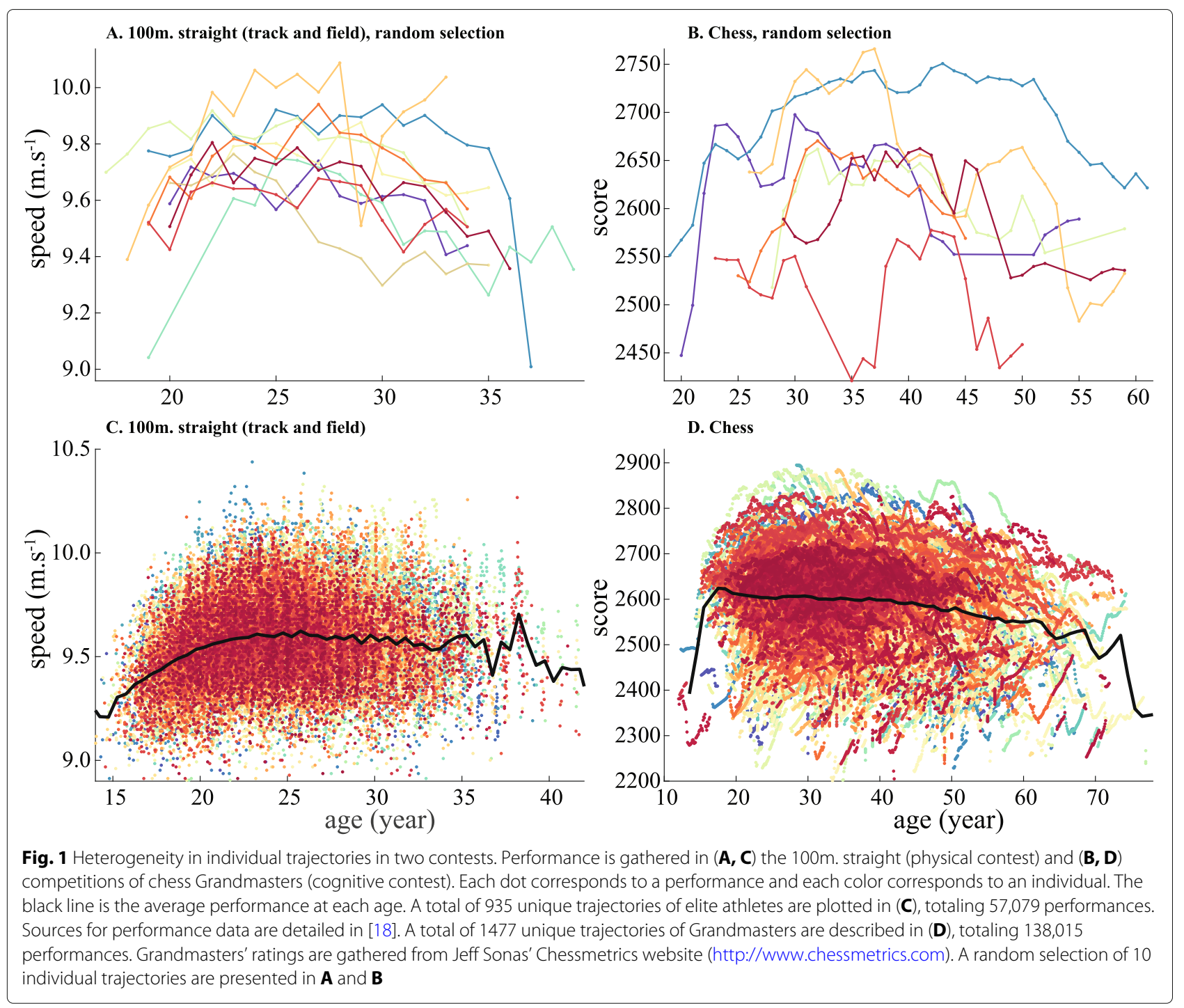

older adults, sarcopenia, frailty and osteoporosis can be major concerns therefore, strength training exercises may be particularly beneficial [55-57]. Physical activity has strong benefits for maintaining functional independence and health-related quality of life, in addition to possible lifespan extension. $[58,59]$. There is empirical evidence of the anti-inflammatory effects of physical activity [60, 61]. Chronic inflammation has deleterious effects on physiological function [62], increasing the risk and progression of chronic diseases such as several types of cancer, [63] cardiovascular disease, and the risk of mortality [64]. The benefits of physical activity appears to depend on the amount of weekly activity in a non-linear fashion [65, 66]. The minimum amount of physical activity affecting mortality is estimated at $15 \mathrm{~min}$ per day, resulting in 3 years of increased longevity [67]. Much higher doses, such as practiced by highly trained athletes, engaged in about ten times the amount recommended by the WHO, has been associated with 7 years of increased life expectancy $[68,69]$. Greater levels of physical activity, even at advanced ages, seems to result in maintenance of functional capacity, that may prevent age-related decline and favor a longer lifespan $[54,70]$. The slower rate of functional decline has been shown to be predictive of lower mortality rates. Previous studies have shown that walking speed is inversely related to all-cause mortality [71, 72]. Walking under $3 \mathrm{~km} /$ hour was related with a higher probability of death in the following 5 years [73, 74]. Lower grip strength, assessed by dynamometer, is related to both musculoskeletal disorders but, more importantly, with allcause mortality [75]. A recent study showed an association between the number of push-ups and the risk of cardiovascular events in midlife [76]. The converging evidence suggests an complex association between physical activity, measures of functional capabilities, and longevity. Lazurus and Harridge introduced the 'Set Point Theory' which 

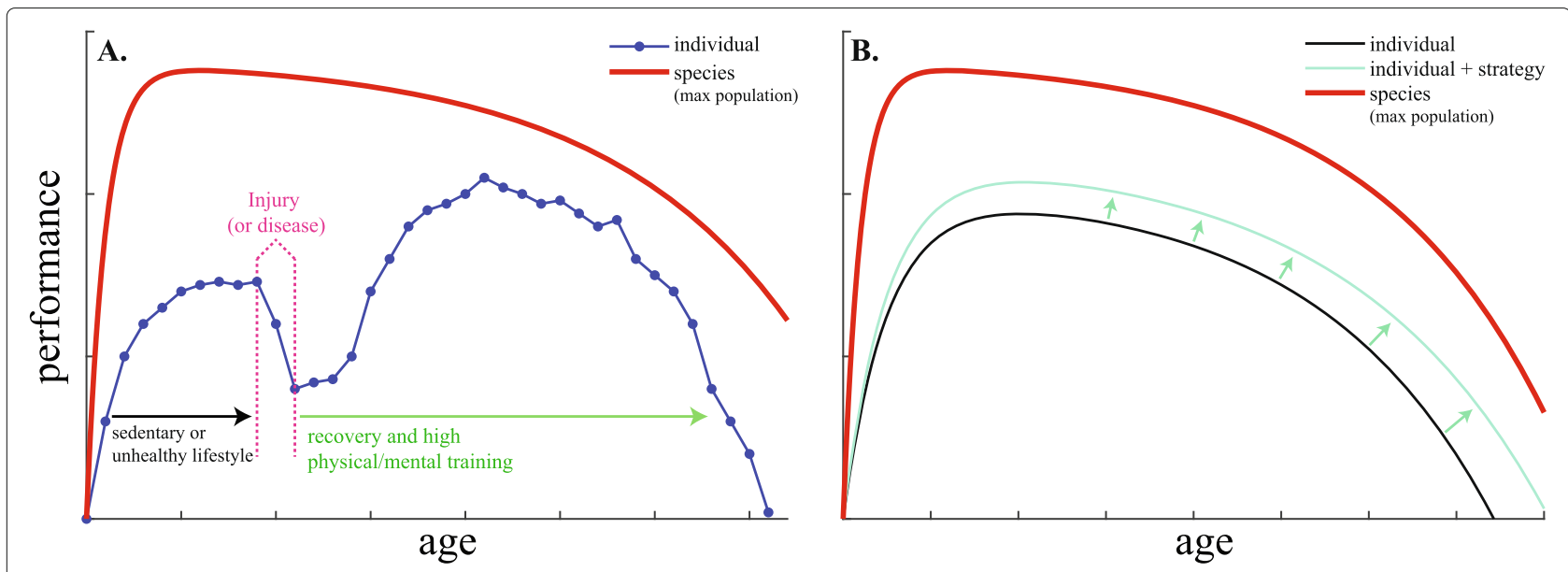

Fig. 2 History of individual trajectories and strategies to expand the $\frown$; Performance against age in arbitrary units for $(\mathbf{A})$ an individual that alters his $\curvearrowright$ in a self autonomous manner and $(\mathbf{B})$ effect of a beneficial strategy on another individual $\frown$. The $\cap$ described in $(\mathbf{A})$ is the result of perturbations associated with (i) detrimental lifestyle (such as sedentary behavior) in early childhood, (ii) an injury or disease affecting the performance and (iii) a major change in lifestyle that results in an artificial, delayed age of peak performance occurring much later in life. In (B) we show how a beneficial strategy is expected to expand the $\cap$, providing room for an increase in performance

hypothesizes that a given amount of physical activity is needed to optimize health with aging, maximizing the 'healthspan' [77]. Their analysis is based solely on the decreasing part of the $\curvearrowright$, but as detailed above the decrease in performance is complex in all situations studied. Given the inevitable age-related decline in functional capacity, accompanied by degeneration in multiple organ systems, it is important to identify targets that could compress morbidity. Physical activity is one such target, with benefits for health that have therapeutic and societal value.

The effect of physical activity on mental health is currently being investigated with heterogeneous results. Some researches suggest that physical activity may delay the onset of neurodegenerative processes and can be a potential adjunctive treatment for neuropsychiatric disorders such as depression [78-80] and cognitive impairment [81]. Physical activity might also be a promising strategy for dementia prevention and disease modification [82], although this is a late-stage disease. Fiatarone Singh et al. showed the biggest effect size with strength training, thus far recorded, in delaying cognitive decline at an early stage (mild cognitive impairment) [83] (see also [84, 85]). But the effect is not so clear, as other studies pointed out that physical activity does not slow cognitive impairment in people with mild to moderate dementia [86]. There also seems to be little evidence of a neuroprotective effect of physical activity when investigating such effects in the Whitehall II cohort study [87], although the Framingham study shows clear effects on brain volume in the elderly [88]. On the other hand, several researches showed that cognitive training seems to be associated with a reduction in the risk of dementia $[89,90]$.

\section{Nutritional strategies}

Another possible approach for hindering the age-related decline in functional performance and increasing lifespan is changes in nutritional strategy. Several types of diets can increase chronic inflammation further escalating the risk of degenerative diseases such as type 2 diabetes, stroke, coronary heart disease [91] or increasing size and speed of tumor growth [92]. In addition, caloric restriction (CR) -the decrease in daily food intake by about $30 \%$ - or intermittent fasting -cycling between periods of fasting and eating- are strategies currently being investigated in animal models [93, 94]. It should be noted that calorically restricted and ad libitum-fed animals are relatively sedentary in testing facilities which questions the definition and status of control and CR animals. It seems that animals in the wild have access to food comparable to CR animals in animal facilities but maintain an increased level of activity [95]. Akbaraly et al. also showed that diet quality assessed during midlife was not significantly associated with subsequent risk for dementia but it was associated with risk of mortality [96]. However, it seems obvious that implementing CR in humans is unlikely. Worse, results in humans demonstrate that diets often lead to weight gain in the long term. In a study comparing dieting to nondieting twins, Schur and colleagues demonstrated that those dieting gained more weight over a four-years followup than their non-dieting twin [97]. Long-term weight loss maintenance is thus difficult to sustain [98] which demonstrates the need for alternative strategies. Two of the main alternatives to $C R$ are: 1 ) increasing activity levels and 2) developing drugs that mimic the cellular and molecular pathways of CR (making CR studies mandatory to understand the underlying mechanistic pathways). 
However, as humans have evolved to run and hunt when starved [99-101], this may represent a resolution to some of the controversies surrounding caloric restriction. There is a clear beneficial mechanism to metabolizing keto-acids such as $\beta$-hydroxybutyrate. When starved, the expression of brain-derived neurotrophic factor is promoted which in turn shifts brain metabolism, is trophic to the brain, and anti-inflammatory therefore, potentially aiding with age related cognitive decline. This can be simply performed by exercising in the morning, while having fasted overnight. This practice forces the body to use keto-acids as its major source of energy thereby making a major metabolic shift. Measuring increased physical activity using activity monitors has shown increased brain volume in the elderly [88]. Ideally, a combination of nutritional, behavioral and therapeutic interventions could lead to strong synergic beneficial effects for a better healthspan and longer lifespan, constituting a direction for future research.

\section{Threats and opportunities}

The major growth of physical performance and capabilities during the twentieth century has been associated with considerable increases in life expectancy, which has doubled in the past 150 years [102, 103]. It was supported by a massive exploitation of fossil fuel energies that greatly contributed to the increase in food production, human reproduction, sport performances, lifespan and human height among others $[103,104]$. This phenotypic expansion - also called techno-physio evolution by Fogel $[105,106]$ - comes at the expense of a major ecological collapse that also affects health through pollutants, climatic changes and resource depletion, thus limiting, or even reversing, the expansion pattern. Major changes in current policies should be rapidly taken in order to limit such detrimental effects. Reversing sedentary behavior through the promotion of physical and mental activity and adopting a healthier lifestyle are beneficial strategies that would help reduce the performance drop and possibly delay the appearance of chronic disease [53, 107109]. Finally, technological innovation, through pharmacology, robotic or neural prostheses may allow for an increased recovery from injuries while delaying chronic disease effects (Fig. 2a \& b). Increased knowledge of the biological mechanisms leading to performance decline in cells and tissues through experimental research would also allow for targeting new biochemical elements [110, 111] and additional strategies for altering the decrease in performance. However, the performance decline is difficult to escape, even among well-trained athletes. If so, multiple mechanisms associated with the generation of multiple age-related diseases would be involved. It is clear that metabolism is compromised at an early stage in neurodegenerative diseases associated with ageing [112] which may well be modifiable.

\section{Abbreviations}

$\frown$ Continuous, Asymmetrical Inverted-U Pattern CR: Caloric restriction

\section{Acknowledgements}

This work is supported by Insitut National du Sport, de l'Expertise et de la Performance (INSEP) and Université de Paris.

\section{Authors' contributions}

GB, PN and SJ led the writing of the manuscript. All authors contributed critically to the drafts and gave final approval for publication. All authors read and approved the final manuscript.

\section{Funding}

No funding was received.

\section{Availability of data and materials}

Not applicable.

\section{Ethics approval and consent to participate}

Not applicable.

\section{Consent for publication}

Not applicable.

\section{Competing interests}

The authors declare that they have no competing interests.

\section{Author details}

${ }^{1}$ IRMES, INSEP, 11 avenue du Tremblay, 75012 Paris, France. ${ }^{2}$ EA 7329, Université de Paris, 12 rue de l'Ecole de Médecine, 75006 Paris, France. ${ }^{3}$ REsearch LAboratory for Interdisciplinary Studies (RELAIS), Paris, France. ${ }^{4}$ Université Côte d'Azur, LAMHESS, Nice, France. ${ }^{5}$ UMR CNRS-MNHN 7179, Brunoy, France. ${ }^{6}$ School of Biological Sciences, Washington State University, WA 99164-4236 Pullman, United States of America. ${ }^{7}$ IUPHAR and Spedding Research Solutions SAS, 78110 Le Vésinet, France. ${ }^{8} 8$ Université de Paris, Inserm U1153, Paris, France. ${ }^{9}$ Department of Epidemiology and Public Health, University College London, London, United Kingdom. ${ }^{10} \mathrm{CIMS}$, Hôtel-Dieu, Assistance Publique - Hôpitaux de Paris, Paris, France.

Received: 18 June 2019 Accepted: 27 October 2019

Published online: 09 December 2019

\section{References}

1. Marck A, Antero J, Berthelot G, Johnson S, Sedeaud A, Leroy A, Marc A, Spedding M, Di Meglio J-M, Toussaint J-F. Age-related upper limits in physical performances. J Gerontol Ser A. 2018;74(5):591-9. https://doi. org/10.1093/gerona/gly 165 .

2. Berthelot G, Sedeaud A, Marck A, Antero-Jacquemin J, Schipman J, Sauliere G, Marc A, Desgorces F-D, Toussaint J-F. Has athletic performance reached its peak? Sports Med. 2015;45(9):1263-71. https:// doi.org/10.1007/s40279-015-0347-2.

3. Haïda A, Coulmy N, Dor F, Antero-Jacquemin J, Marc A, Ledanois T, Tourny C, Rousseaux-Blanchi MP, Chambat P, Sedeaud A, et al. Return to sport among french alpine skiers after an anterior cruciate ligament rupture: results from 1980 to 2013. Am J Sports Med. 2016;44(2):324-30. https://doi.org/10.1177/0363546515612764.

4. Hawley JA, Hargreaves M, Joyner MJ, Zierath JR. Integrative biology of exercise. Cell. 2014;159(4):738-49. https://doi.org/10.1016/j.cell.2014.10. 029.

5. Tanaka H, Seals DR. Endurance exercise performance in masters athletes: age-associated changes and underlying physiological mechanisms. J Physiol. 2008;586(1):55-63. https://doi.org/10.1113/ jphysiol.2007.141879.

6. Böttiger L. Regular decline in physical working capacity with age. Br Med J. 1973;3(5874):270-1. https://doi.org/10.1136/bmj.3.5874.270.

7. IImarinen JE. Aging workers. Occup Environ Med. 2001;58(8):546-6. https://doi.org/10.1136/oem.58.8.546.

8. Murman DL. The impact of age on cognition. In: Seminars in Hearing, vol. 36. Thieme Medical Publishers; 2015. p. 111-21. https://doi.org/10. 1055/s-0035-1555115. 
9. Germine LT, Duchaine B, Nakayama K. Where cognitive development and aging meet: Face learning ability peaks after age 30. Cognition. 2011;118(2):201-10. https://doi.org/10.1016/j.cognition.2010.11.002.

10. Boot AM, de Ridder MA, van der Sluis IM, van Slobbe I, Krenning EP, de Muinck Keizer-Schrama SM. Peak bone mineral density, lean body mass and fractures. Bone. 2010;46(2):336-41. https://doi.org/10.1016/j.bone. 2009.10.003.

11. Kühnert B, Nieschlag E. Reproductive functions of the ageing male. Hum Reprod Update. 2004;10(4):327-39. https://doi.org/10.1093/ humupd/dmh030

12. Salthouse TA. When does age-related cognitive decline begin? Neurobiol Aging. 2009;30(4):507-14. https://doi.org/10.1016/j. neurobiolaging.2008.09.023.

13. Schoenberg JB, Beck GJ, Bouhuys A. Growth and decay of pulmonary function in healthy blacks and whites. Respir Physiol. 1978;33(3):367-93. https://doi.org/10.1016/0034-5687(78)90063-4.

14. Marck A, Berthelot G, Foulonneau V, Marc A, Antero-Jacquemin J, Noirez P, Bronikowski AM, Morgan TJ, Garland T, Carter PA, et al. Age-related changes in locomotor performance reveal a similar pattern for caenorhabditis elegans, mus domesticus, canis familiaris, equus caballus, and homo sapiens. J Gerontol Ser A. 2017;72(4):455-63. https:// doi.org/10.1093/gerona/glw136.

15. Baker $A B$, Tang $Y Q$. Aging performance for masters records in athletics, swimming, rowing, cycling, triathlon, and weightlifting. Exp Aging Res. 2010;36(4):453-77. https://doi.org/10.1080/0361073x.2010.507433.

16. Faulkner JA, Larkin LM, Claflin DR, Brooks SV. Age-related changes in the structure and function of skeletal muscles. Clin Exp Pharmacol Physiol. 2007;34(11):1091-6. https://doi.org/10.1111/j.1440-1681.2007.04752.x.

17. Berthelot $G$, Len $S$, Hellard $P$, Tafflet M, Guillaume M, Vollmer J-C, Gager B, Quinquis L, Marc A, Toussaint J-F. Exponential growth combined with exponential decline explains lifetime performance evolution in individual and human species. Age. 2012;34(4):1001-9. https://doi.org/10.1007/s11357-011-9274-9.

18. Berthelot G, Bar-Hen A, Marck A, Foulonneau V, Douady S, Noirez P, Zablocki-Thomas PB, da Silva Antero J, Carter PA, Di Meglio J-M, et al. An integrative modeling approach to the age-performance relationship in mammals at the cellular scale. Sci Rep. 2019;9(1):418. https://doi.org/ 10.1038/s41598-018-36707-3.

19. Singh-Manoux A, Kivimaki M, Glymour MM, Elbaz A, Berr C, Ebmeier KP, Ferrie JE, Dugravot A. Timing of onset of cognitive decline: results from whitehall ii prospective cohort study. Bmj. 2012;344:7622. https:// doi.org/10.1136/bmj.d7622.

20. Dharmalingam A, Navaneetham K, Krishnakumar C. Nutritional status of mothers and low birth weight in india. Matern Child Health J. 2010;14(2): 290-8. https://doi.org/10.1007/s10995-009-0451-8.

21. Thame M, Wilks RJ, McFarlane-Anderson N, Bennett FI, Forrester TE. Relationship between maternal nutritional status and infant's weight and body proportions at birth. Eur J Clin Nutr. 1997;51(3):134. https://doi. org/10.1038/sj.ejen.1600357.

22. Rahman M, Roy S, Ali M, Mitra A, Alam A, Akbar M. Maternal nutritional status as a determinant of child health. J Trop Pediatr. 1993;39(2):86-8. https://doi.org/10.1111/j.1740-8709.2005.00016.x.

23. Rao S, Yajnik CS, Kanade A, Fall CH, Margetts BM, Jackson AA, Shier R, Joshi $\mathrm{S}$, Rege $\mathrm{S}$, Lubree $\mathrm{H}$, et al. Intake of micronutrient-rich foods in rural indian mothers is associated with the size of their babies at birth: Pune maternal nutrition study. J Nutr. 2001;131(4):1217-24. https://doi. org/10.1093/jn/131.4.1217.

24. Vaiserman AM. Birth weight predicts aging trajectory: A hypothesis. Mech Ageing Dev. 2018. https://doi.org/10.1016/j.mad.2018.04.003.

25. Nandi A, Bhalotra S, Deolalikar AB, Laxminarayan R. The human capital and productivity benefits of early childhood nutritional interventions. In: Bundy DAP, Silva HSeaNd, editors. Child and Adolescent Health and Development. 3rd Edition. Chap. 27. Washington (DC): The International Bank for Reconstruction and Development/The World Bank; 2017. https://doi.org/10.1596/978-1-4648-0423-6 ch27.

26. Aldrich TK, Gustave J, Hall CB, Cohen HW, Webber MP, Zeig-Owens R, Cosenza K, Christodoulou V, Glass L, Al-Othman F, et al. Lung function in rescue workers at the world trade center after 7 years. N Engl J Med. 2010;362(14):1263-72. https://doi.org/10.1056/nejmoa0910087.

27. Giorgini P, Rubenfire M, Bard RL, Jackson EA, Ferri C, Brook RD. Air pollution and exercise: A review of the cardiovascular implications for health care professionals. J Cardiopulm Rehab Prev. 2016;36(2):84-95. https://doi.org/10.1097/HCR.0000000000000139.
28. Mitchell WK, Atherton PJ, Williams J, Larvin M, Lund JN, Narici M. Sarcopenia, dynapenia, and the impact of advancing age on human skeletal muscle size and strength; a quantitative review. Front Physiol. 2012;3:260. https://doi.org/10.3389/fphys.2012.00260.

29. Constantin D, McCullough J, Mahajan RP, Greenhaff PL. Novel events in the molecular regulation of muscle mass in critically ill patients. J Physiol. 2011;589(15):3883-95. https://doi.org/10.1113/jphysiol.2011.206193.

30. Hayflick L. Entropy explains aging, genetic determinism explains longevity, and undefined terminology explains misunderstanding both. PLoS Genet. 2007;3(12): https://doi.org/10.1371/journal.pgen.0030220.

31. Simonton DK. Age and outstanding achievement: What do we know after a century of research? Psychol Bull. 1988;104(2):251. https://doi. org/10.1037//0033-2909.104.2.251

32. Allen SV, Hopkins WG. Age of peak competitive performance of elite athletes: a systematic review. Sports Med. 2015;45(10):1431-41. https:// doi.org/10.1007/s40279-015-0354-3.

33. Lara B, Salinero JJ, Del Coso J. The relationship between age and running time in elite marathoners is u-shaped. Age. 2014;36(2):1003-8. https://doi.org/10.1007/s11357-013-9614-z.

34. Moore DH. A study of age group track and field records to relate age and running speed. Nature. 1975;253:264-5. https://doi.org/10.1038/ 253264a0

35. Guillaume M, Len S, Tafflet M, Quinquis L, Montalvan B, Schaal K, Nassif H, Desgorces F, Toussaint J-F. Success and decline: Top 10 tennis players follow a biphasic course. Med Sci Sports Exerc. 2011;43(11): 2148-54. https://doi.org/10.1249/mss.0b013e31821eb533.

36. Malcata RM, Hopkins WG, Pearson SN. Tracking career performance of successful triathletes. Med Sci Sports Exerc. 2014;46(6):1227-34. https:// doi.org/10.1249/mss.0000000000000221.

37. Dill DB. Marathoner demar: physiological studies. J Natl Cancer Inst. 1965;35(1):185-91. https://doi.org/10.1093/jnci/35.1.185.

38. Morgan TJ, Garland Jr T, Carter PA. Ontogenies in mice selected for high voluntary wheel-running activity. i. mean ontogenies. Evolution. 2003;57(3):646-57. https://doi.org/10.1111/j.0014-3820.2003.tb01556.x.

39. Bronikowski A, Morgan T, Garland Jr T, Carter P. The evolution of aging and age-related physical decline in mice selectively bred for high voluntary exercise. Evolution. 2006;60(7):1494-508. https://doi.org/10. 1554/05-590.1.

40. Le Bourg É, Minois N. A mild stress, hypergravity exposure, postpones behavioral aging in drosophila melanogaster1. Exp Gerontol. 1999;34(2): 157-172. https://doi.org/10.1016/s0531-5565(98)00077-1.

41. Vance JT, Williams JB, Elekonich MM, Roberts SP. The effects of age and behavioral development on honey bee (apis mellifera) flight performance. J Exp Biol. 2009;212(16):2604-11. https://doi.org/10.1242/ jeb.028100.

42. Schumacher P, Weyeneth A, Weber DC, Dorn S. Long flights in cydia pomonella I.(lepidoptera: Tortricidae) measured by a flight mill: influence of sex, mated status and age. Physiol Entomol. 1997;22(2): 149-60. https://doi.org/10.1111/j.1365-3032.1997.tb01152.x.

43. Ingram DK. Age-related decline in physical activity: generalization to nonhumans. Med Sci Sports Exerc. 2000;32(9):1623-9. https://doi.org/ 10.1097/00005768-200009000-00016.

44. Gilbert MJ, Zerulla TC, Tierney KB. Zebrafish (danio rerio) as a model for the study of aging and exercise: physical ability and trainability decrease with age. Exp Gerontol. 2014;50:106-13. https://doi.org/10.1016/j.exger. 2013.11.013.

45. Justice JN, Cesari M, Seals DR, Shively CA, Carter CS. Comparative approaches to understanding the relation between aging and physical function. J Gerontol Ser A Biomed Sci Med Sci. 2015;71 (10):1243-53. https://doi.org/10.1093/gerona/glv035.

46. Nassif $H$, Sedeaud A, Abidh E, Schipman J, Tafflet M, Deschamps T, Maillet H, Ovigneur H, Desgorces F-D, Toussaint J-F. Monitoring fitness levels and detecting implications for health in a french population: an observational study. BMJ open. 2012;2(5):001022. https://doi.org/10. 1136/bmjopen-2012-001022.

47. Hall KS, Cohen HJ, Pieper CF, Fillenbaum GG, Kraus WE, Huffman KM, Cornish MA, Shiloh A, Flynn C, Sloane R, et al. Physical performance across the adult life span: correlates with age and physical activity. J Gerontol Ser A Biomed Sci Med Sci. 2016;72(4):572-8. https://doi.org/10. 1093/gerona/glw120

48. Bongard V, McDermott AY, Dallal GE, Schaefer EJ. Effects of age and gender on physical performance. Age. 2007;29(2-3):77-85. https://doi. org/10.1007/s11357-007-9034-z. 
49. Belsky DW, Caspi A, Houts R, Cohen HJ, Corcoran DL, Danese A, Harrington H, Israel S, Levine ME, Schaefer JD, et al. Quantification of biological aging in young adults. Proc Natl Acad Sci. 2015;112(30): 4104-10. https://doi.org/10.1073/pnas.1506264112.

50. Penedo FJ, Dahn JR. Exercise and well-being: a review of mental and physical health benefits associated with physical activity. Curr Opin Psychiatr. 2005;18(2):189-93. https://doi.org/10.1097/00001504200503000-00013.

51. Ortega FB, Silventoinen $K$, Tynelius P, Rasmussen F. Muscular strength in male adolescents and premature death: cohort study of one million participants. Bmj. 2012;345:7279. https://doi.org/10.1136/bmj.e7279.

52. Lim SS, Vos T, Flaxman AD, Danaei G, Shibuya K, Adair-Rohani H, AlMazroa MA, Amann M, Anderson HR, Andrews KG, et al. A comparative risk assessment of burden of disease and injury attributable to 67 risk factors and risk factor clusters in 21 regions, 1990-2010: a systematic analysis for the global burden of disease study 2010. Lancet. 2012;380(9859):2224-60. https://doi.org/10.1016/S0140-6736(12)617668.

53. Saint-Maurice PF, Coughlan D, Kelly SP, Keadle SK, Cook MB, Carlson $\mathrm{SA}$, Fulton JE, Matthews CE. Association of leisure-time physical activity across the adult life course with all-cause and cause-specific mortality. JAMA Netw Open. 2019;2(3):190355. https://doi.org/10.1001/ jamanetworkopen.2019.0355.

54. Lazarus NR, Lord JM, Harridge SD. The relationships and interactions between age, exercise and physiological function. J Physiol. 2019;597(5): 1299-309. https://doi.org/10.1113/jp277071.

55. Lee S-Y, Tung H-H, Liu C-Y, Chen L-K. Physical activity and sarcopenia in the geriatric population: a systematic review. J Am Med Dir Assoc. 2018;19(5):378-83.

56. Piercy KL, Troiano RP, Ballard RM, Carlson SA, Fulton JE, Galuska DA, George SM, Olson RD. The physical activity guidelines for americans. Jama. 2018;320(19):2020-8.

57. DiPietro L, Campbell WW, Buchner DM, Erickson Kl, Powell KE, Bloodgood B, Hughes T, Day KR, Piercy KL, Vaux-Bjerke A, et al. Physical activity, injurious falls, and physical function in aging: An umbrella review. Med Sci Sports Exerc. 2019;51(6):1303-13.

58. Marzetti E, Calvani R, Tosato M, Cesari M, Di Bari M, Cherubini A, Broccatelli M, Savera G, D'Elia M, Pahor M, et al. Physical activity and exercise as countermeasures to physical frailty and sarcopenia. Aging Clin Exp Res. 2017;29(1):35-42.

59. Cruz-Jentoft A, Landi F, Schneider S, Zúñiga C, Arai H, Boirie Y, Chen L, Fielding R, Martin F, Michel J, et al. Report of the international sarcopenia initiative (ewgsop and iwgs). prevalence of and interventions for sarcopenia in ageing adults: a systematic review. Age Ageing. 2014;43:748-59.

60. Flynn MG, McFarlin BK, Markofski MM. State of the art reviews: The anti-inflammatory actions of exercise training. Am J Lifestyle Med. 2007;1(3):220-35. https://doi.org/10.1177/1559827607300283.

61. Smith L, Yang L, Hamer M. Handgrip strength, inflammatory markers and mortality. Scand J Med Sci Sports. 2019. https://doi.org/10.1111/ sms.13433.

62. Hunter P. The inflammation theory of disease: The growing realization that chronic inflammation is crucial in many diseases opens new avenues for treatment. EMBO Rep. 2012;13(11):968-70. https://doi.org/ 10.1038/embor.2012.142

63. Moore SC, Lee I-M, Weiderpass E, Campbell PT, Sampson JN, Kitahara CM, Keadle SK, Arem H, de Gonzalez AB, Hartge P, et al. Association of leisure-time physical activity with risk of 26 types of cancer in 1.44 million adults. JAMA Intern Med. 2016;176(6):816-825. https://doi.org/ 10.1001/jamainternmed.2016.1548.

64. Arai Y, Martin-Ruiz CM, Takayama M, Abe Y, Takebayashi T, Koyasu S, Suematsu M, Hirose N, von Zglinicki T. Inflammation, but not telomere length, predicts successful ageing at extreme old age: A longitudinal study of semi-supercentenarians. EBioMedicine. 2015;2(10):1549-58. https://doi.org/10.1016/j.ebiom.2015.07.029.

65. Schnohr P, O'Keefe JH, Marott IL, Lange P, Jensen GB. Dose of jogging and long-term mortality: the copenhagen city heart study. J Am Coll Cardiol. 2015;65(5):411-9. https://doi.org/10.1016/j.jacc.2014.11.023.

66. Lee I-M, Skerrett PJ. Physical activity and all-cause mortality: what is the dose-response relation? Med Sci Sports Exerc. 2001;33(6):459-471. https://doi.org/10.1097/00005768-200106001-00016.
67. Wen CP, Wai JPM, Tsai MK, Yang YC, Cheng TYD, Lee M-C, Chan HT, Tsao CK, Tsai SP, Wu X. Minimum amount of physical activity for reduced mortality and extended life expectancy: a prospective cohort study. Lancet. 2011;378(9798):1244-53. https://doi.org/10.1016/s01406736(11)60749-6.

68. Antero-Jacquemin J, Pohar-Perme M, Rey G, Toussaint J-F, Latouche A. The heart of the matter: years-saved from cardiovascular and cancer deaths in an elite athlete cohort with over a century of follow-up. Eur J Epidemiol. 2018;33(6):531-43. https://doi.org/10.1007/s10654-0180401-0.

69. Garatachea N, Pareja-Galeano H, Sanchis-Gomar F, Santos-Lozano A, Fiuza-Luces C, Morán M, Emanuele E, Joyner MJ, Lucia A. Exercise attenuates the major hallmarks of aging. Rejuvenation Res. 2015;18(1): 57-89. https://doi.org/10.1089/rej.2014.1623.

70. Byberg L, Melhus H, Gedeborg R, Sundström J, Ahlbom A, Zethelius B, Berglund LG, Wolk A, Michaëlsson K. Total mortality after changes in leisure time physical activity in 50 year old men: 35 year follow-up of population based cohort. Bmj. 2009;338:688. https://doi.org/10.1136/ bmj.b688.

71. Yates T, Zaccardi F, Dhalwani NN, Davies MJ, Bakrania K, Celis-Morales CA, Gill JM, Franks PW, Khunti K. Association of walking pace and handgrip strength with all-cause, cardiovascular, and cancer mortality: a uk biobank observational study. Eur Heart J. 2017;38(43):3232-40. https://doi.org/10.1007/s10654-018-0401-0.

72. Studenski S, Perera S, Patel K, Rosano C, Faulkner K, Inzitari M, Brach J, Chandler J, Cawthon P, Connor EB, et al. Gait speed and survival in older adults. Jama. 2011;305(1):50-8. https://doi.org/10.1001/jama.2010.1923.

73. Stanaway FF, Gnjidic D, Blyth FM, Le Couteur DG, Naganathan V, Waite L, Seibel MJ, Handelsman DJ, Sambrook PN, Cumming RG. How fast does the grim reaper walk? receiver operating characteristics curve analysis in healthy men aged 70 and over. Bmj. 2011;343:7679. https:// doi.org/10.1136/bmj.d7679.

74. Franklin BA, Brinks J, Sacks R, Trivax J, Friedman H. Reduced walking speed and distance as harbingers of the approaching grim reaper. Am J Cardiol. 2015;116(2):313-7. https://doi.org/10.1016/j.amjcard.2015.04. 024.

75. Leong DP, Teo KK, Rangarajan S, Lopez-Jaramillo P, Avezum Jr A, Orlandini A, Seron P, Ahmed SH, Rosengren A, Kelishadi R, et al. Prognostic value of grip strength: findings from the prospective urban rural epidemiology (pure) study. Lancet. 2015;386(9990):266-73. https:// doi.org/10.1016/s0140-6736(14)62000-6.

76. Yang J, Christophi CA, Farioli A, Baur DM, Moffatt S, Zollinger TW, Kales SN. Association between push-up exercise capacity and future cardiovascular events among active adult men. JAMA network open. 2019;2(2):188341. https://doi.org/10.1001/jamanetworkopen.2018.8341.

77. Lazarus NR, Harridge SD. Declining performance of master athletes: silhouettes of the trajectory of healthy human ageing? J Physiol. 2017;595(9):2941-8. https://doi.org/10.1113/jp272443.

78. Blumenthal JA, Smith PJ, Hoffman BM. Is exercise a viable treatment for depression? ACSM's Health Fit J. 2012;16(4):14. https://doi.org/10.1249/ 01.FIT.0000416000.09526.eb.

79. Overdorf V, Kollia B, Makarec K, Alleva Szeles C. The relationship between physical activity and depressive symptoms in healthy older women. Gerontol Geriatr Med. 2016;2:2333721415626859. https://doi. org/10.1177/2333721415626859.

80. Ballesteros $\mathrm{S}$, Kraft E, Santana S, Tziraki C. Maintaining older brain functionality: a targeted review. Neurosci Biobehav Rev. 2015;55:453-77. https://doi.org/10.1016/j.neubiorev.2015.06.008.

81. Deslandes A, Moraes H, Ferreira C, Veiga H, Silveira H, Mouta R, Pompeu FA, Coutinho ESF, Laks J. Exercise and mental health: many reasons to move. Neuropsychobiology. 2009;59(4):191-8. https://doi. org/10.1159/000223730.

82. Ahlskog JE, Geda YE, Graff-Radford NR, Petersen RC. Physical exercise as a preventive or disease-modifying treatment of dementia and brain aging. In: Mayo Clinic Proceedings, vol. 86. Elsevier; 2011. p. 876-84. https://doi.org/10.4065/mcp.2011.0252

83. Singh MAF, Gates N, Saigal N, Wilson GC, Meiklejohn J, Brodaty H, Wen W, Singh N, Baune BT, Suo C, et al. The study of mental and resistance training (smart) study - resistance training and/or cognitive training in mild cognitive impairment: a randomized, double-blind, double-sham controlled trial. J Am Med Dir Assoc. 2014;15(12):873-80. https://doi.org/10.1016/j.jamda.2014.09.010. 
84. Heffernan M, Andrews G, Fiatarone Singh MA, Valenzuela M, Anstey KJ, Maeder A, McNeil J, Jorm L, Lautenschlager N, Sachdev P, et al. Maintain your brain: Protocol of a 3-year randomized controlled trial of a personalized multi-modal digital health intervention to prevent cognitive decline among community dwelling 55 to 77 year olds. J Alzheimer Dis. 20181-17. (Preprint). https://doi.org/10.3233/jad-180572.

85. Mavros Y, Gates N, Wilson GC, Jain N, Meiklejohn J, Brodaty H, Wen W, Singh N, Baune BT, Suo C, et al. Mediation of cognitive function improvements by strength gains after resistance training in older adults with mild cognitive impairment: outcomes of the study of mental and resistance training. J Am Geriatr Soc. 2017;65(3):550-9. https://doi.org/ $10.1111 /$ jgs. 14542

86. Lamb SE, Sheehan B, Atherton N, Nichols V, Collins H, Mistry D, Dosanjh S, Slowther AM, Khan I, Petrou S, et al. Dementia and physical activity (dapa) trial of moderate to high intensity exercise training for people with dementia: randomised controlled trial. bmj. 2018;361:1675. https://doi.org/10.1136/bmj.k1675.

87. Sabia S, Dugravot A, Dartigues J-F, Abell J, Elbaz A, Kivimäki M, Singh-Manoux A. Physical activity, cognitive decline, and risk of dementia: 28 year follow-up of whitehall ii cohort study. bmj. 2017;357: 2709. https://doi.org/10.1136/bmj.j2709.

88. Spartano NL, Davis-Plourde KL, Himali JJ, Andersson C, Pase MP, Maillard P, DeCarli C, Murabito JM, Beiser AS, Vasan RS, et al. Association of accelerometer-measured light-intensity physical activity with brain volume: The framingham heart study. JAMA Netw Open. 2019;2(4):192745. https://doi.org/10.1001/jamanetworkopen.2019.2745.

89. Valenzuela M, Sachdev P. Can cognitive exercise prevent the onset of dementia? systematic review of randomized clinical trials with longitudinal follow-up. Am J Geriatr Psychiatr. 2009;17(3):179-187. https://doi.org/jgp.0b013e3181953b57.

90. Gates N, Valenzuela M. Cognitive exercise and its role in cognitive function in older adults. Curr Psychiatr Rep. 2010;12(1):20-7. https://doi. org/10.1007/s11920-009-0085-y

91. Galland L. Diet and inflammation. Nutr Clin Pract. 2010;25(6):634-40. https://doi.org/10.1177/0884533610385703.

92. Peeters K, Leemputte FV, Fischer B, Bonini BM, Quezada H, Tsytlonok M, Haesen D, Vanthienen W, Bernardes N, González-Blas CB, Janssens V, Tompa P, Versées W, Thevelein JM. Fructose-1,6-bisphosphate couples glycolytic flux to activation of ras. In: Nature Communications; 2017. https://doi.org/10.1038/s41467-017-01019-z.

93. Wahl D, Cogger VC, Solon-Biet SM, Waern RV, Gokarn R, Pulpitel T, de Cabo R, Mattson MP, Raubenheimer D, Simpson SJ, et al. Nutritional strategies to optimise cognitive function in the aging brain. Ageing Res Rev. 2016;31:80-92. https://doi.org/10.1016/j.arr.2016.06.006.

94. Pifferi F, Terrien J, Perret M, Epelbaum J, Blanc S, Picq J-L, Dhenain M, Aujard F. Promoting healthspan and lifespan with caloric restriction in primates. Commun Biol. 2019;2(1):107. https://doi.org/10.1038/s42003019-0348-z.

95. Martin B, Ji S, Maudsley S, Mattson MP. "control" laboratory rodents are metabolically morbid: why it matters. Proc Natl Acad Sci. 2010;107(14): 6127-33. https://doi.org/10.1073/pnas.0912955107.

96. Akbaraly TN, Singh-Manoux A, Dugravot A, Brunner EJ, Kivimäki M, Sabia S. Association of midlife diet with subsequent risk for dementia. Jama. 2019;321(10):957-68. https://doi.org/10.1001/jama.2019.1432.

97. Schur EA, Heckbert SR, Goldberg JH. The association of restrained eating with weight change over time in a community-based sample of twins. Obesity. 2010;18(6):1146-52. https://doi.org/10.1038/oby.2009.506.

98. Anderson JW, Konz EC, Frederich RC, Wood CL. Long-term weight-loss maintenance: a meta-analysis of us studies. Am J Clin Nutr. 2001;74(5): 579-84. https://doi.org/10.1093/ajcn/74.5.579.

99. Noakes T, Spedding M. Olympics: Run for your life. Nature. 2012;487(7407):295. https://doi.org/10.1038/487295a.

100. Sleiman SF, Henry J, Al-Haddad R, El Hayek L, Haidar EA, Stringer T, Ulja D, Karuppagounder SS, Holson EB, Ratan RR, et al. Exercise promotes the expression of brain derived neurotrophic factor (bdnf) through the action of the ketone body $\beta$-hydroxybutyrate. Elife. 2016;5: 15092. https://doi.org/10.7554/elife.15092.

101. Markham A, Bains R, Franklin P, Spedding M. Changes in mitochondrial function are pivotal in neurodegenerative and psychiatric disorders: how important is bdnf? Br J Pharmacol. 2014;171(8):2206-29. https://doi. org/10.1111/bph.12531.
102. Crimmins EM. Lifespan and healthspan: past, present, and promise. Gerontologist. 2015;55(6):901-11. https://doi.org/10.1093/geront/ gnv130.

103. Marck A, Antero J, Berthelot G, Saulière G, Jancovici J-M, Masson-Delmotte V, Boeuf G, Spedding M, Le Bourg É, Toussaint J-F. Are we reaching the limits of homo sapiens? Front Physiol. 2017;8:812. https://doi.org/10.3389/fphys.2017.00812.

104. Smith KR, Frumkin H, Balakrishnan K, Butler CD, Chafe ZA, Fairlie I, Kinney P, Kjellstrom T, Mauzerall DL, McKone TE, et al. Energy and human health. Ann Rev Public Health. 2013;34:159-88. https://doi.org/ 10.1146/annurev-publhealth-031912-114404.

105. Fogel RW. Technophysio evolution and the measurement of economic growth. J Evol Econ. 2004;14(2):217-21. https://doi.org/10.1007/s00191004-0188-x.

106. Fogel R. The Escape from Hunger and Premature Death, 1700-2100: Europe, America and the Third World. Cambridge: Cambridge University Press; 2004. https://doi.org/10.1017/cbo9780511817649.

107. Bailey R, Hillman C, Arent S, Petitpas A. Physical activity: An underestimated investment in human capital? J Phys Act Health. 2013;10(3):289-308. https://doi.org/10.1123/jpah.10.3.289. https://doi.org/10.1123/jpah.10.3.289.

108. Holme I, Anderssen SA. Increases in physical activity is as important as smoking cessation for reduction in total mortality in elderly men: 12 years of follow-up of the oslo ii study. Br J Sports Med. 2015;49(11): 743-8. https://doi.org/10.1136/bjsports-2014-094522.

109. Thivel D, Tremblay A, Genin PM, Panahi S, Rivière D, Duclos M. Physical activity, inactivity, and sedentary behaviors: Definitions and implications in occupational health. Front Public Health. 2018;6:288. https://doi.org/ 10.3389/fpubh.2018.00288.

110. Ryu D, Mouchiroud L, Andreux PA, Katsyuba E, Moullan N, Nicolet-dit-Félix AA, Williams EG, Jha P, Sasso GL, Huzard D, et al. Urolithin a induces mitophagy and prolongs lifespan in C. elegans and increases muscle function in rodents. Nat Med. 2016;22(8):879. https:// doi.org/10.1038/nm.4132.

111. Kim S-J, Mehta HH, Wan J, Kuehnemann C, Chen J, Hu J-F, Hoffman AR, Cohen P. Mitochondrial peptides modulate mitochondrial function during cellular senescence. Aging (Albany NY). 2018;10(6):1239. https:// doi.org/10.18632/aging.101463.

112. Camandola S, Mattson MP. Brain metabolism in health, aging, and neurodegeneration. EMBO J. 2017;36(11):1474-92. https://doi.org/10. 15252/embj.201695810.

\section{Publisher's Note}

Springer Nature remains neutral with regard to jurisdictional claims in published maps and institutional affiliations.
Ready to submit your research? Choose BMC and benefit from:

- fast, convenient online submission

- thorough peer review by experienced researchers in your field

- rapid publication on acceptance

- support for research data, including large and complex data types

- gold Open Access which fosters wider collaboration and increased citations

- maximum visibility for your research: over $100 \mathrm{M}$ website views per year

At BMC, research is always in progress.

Learn more biomedcentral.com/submissions 